\title{
Consistent and Variable Chromosome Anomalies in Parents of Children with Down's Syndrome
}

\author{
J. KAHN and K. ABE* \\ From Medical Research Council, Psychiatric Genetics Research Unit, Institute of Psychiatry, Maudsley Hospital, \\ Denmark Hill, London S.E.5
}

The patients in this series were referred to us after an initial clinical diagnosis of Down's syndrome for either a neurological study (Cowie, 1967) or genetic counselling. The cytogenetic study was aimed at distinguishing between subjects with primary trisomy and those with translocations or any other cytological variant of Down's syndrome. Chromosome studies were undertaken whenever possible. At the same time a small series of patients and parents, referred to us for reasons other than Down's syndrome, were also investigated. Analysis included the scoring of aneuploid cells, cells with structural anomalies, and chromatid breaks. Statistical analysis enabled us to compare some of our material with published chromosome studies on adults (Court Brown et al., 1966; this will be referred to as the Edinburgh survey). The present communication summarizes the results of this study.

\section{Material and Methods}

Over half the patients $(49 / 86)$ formed part of a neurological study based on a population of Down's syndrome births by Cowie (1967); the rest were referred to us because their parents had asked for genetic counselling.

Patients were referred from two geographical areas: (1) part of the County of Surrey under the administration of Surrey County Council before the inauguration of the Greater London Council (not including that part of Surrey included in the administrative Borough of Croydon); (2) area 7 of the former London County Council, which consisted of the Boroughs of Camberwell and Lewisham (Cowie, 1967). During the same period 109 blood samples were cultured from individuals referred to us for genetic counselling, though not because of Down's syndrome.

Chromosome analysis was carried out solely on lymphocytes from 3-day (69-74 hr.) peripheral blood cultures. Blood samples were cultured by the method of

\footnotetext{
Received May 29, 1968.

^ Present address: Department of Psychiatry, Osaka City University, School of Medicine, Osaka, Japan.
}

Moorhead et al. (1960), and slides made using the method of Evans, Breckon, and Ford (1964).

The number of cells analysed varied between cultures, because it was not foreseen from the outset that a statistical analysis of the results would be required. In the majority of cases the number of cells analysed per sample was around 20 (Appendix). The cytogenetical analysis of our sample was compared with data on late cultures of the Edinburgh survey.

\section{Results}

(a) Families without Down's Syndrome. In this series, $9 / 2372$ cells were found with chromatid breaks. An incidence of $0.38 \%$ of chromatid breakage differed clearly from the breakage incidence $(67 / 5345 ; 1.25 \%)$ of the Down's syndrome series, but was in good agreement with the breakage incidence in the Edinburgh survey (total male and female $38 / 8983 ; 0.42 \%$ ). Since this series was not representative of the general population, a more detailed statistical comparison was made between our series of Down's syndrome families and the Edinburgh survey. The present communication summarizes the results of this study.

\section{(b) Patients with Down's Syndrome}

(i) Consistent chromosome anomalies. Of the 86 patients studied, 83 were trisomic for a G group chromosome. One of these, a girl (see (c), Family 1) was in addition heterozygous for a presumptive reciprocal translocation, $47, \mathrm{XX}, \mathrm{G}+, \mathrm{t}(\mathrm{Bp}+; \mathrm{Cq}-)$ mat. (Fig. 1).

Three of the patients had chromosome translocations. Two had a presumptive $\mathrm{G} / \mathrm{G}$ translocation (46,XX,G - , t (GqGq) + ; Families 11 and 26), and one had a presumptive $D / G$ translocation $(46, X Y$, $\mathrm{D}-, \mathrm{t}(\mathrm{DqGq})+$; Family 61).

One affected male (Family 51) had a long Y chromosome, also carried by his father and uncle (see Fig. 3, k-m). 


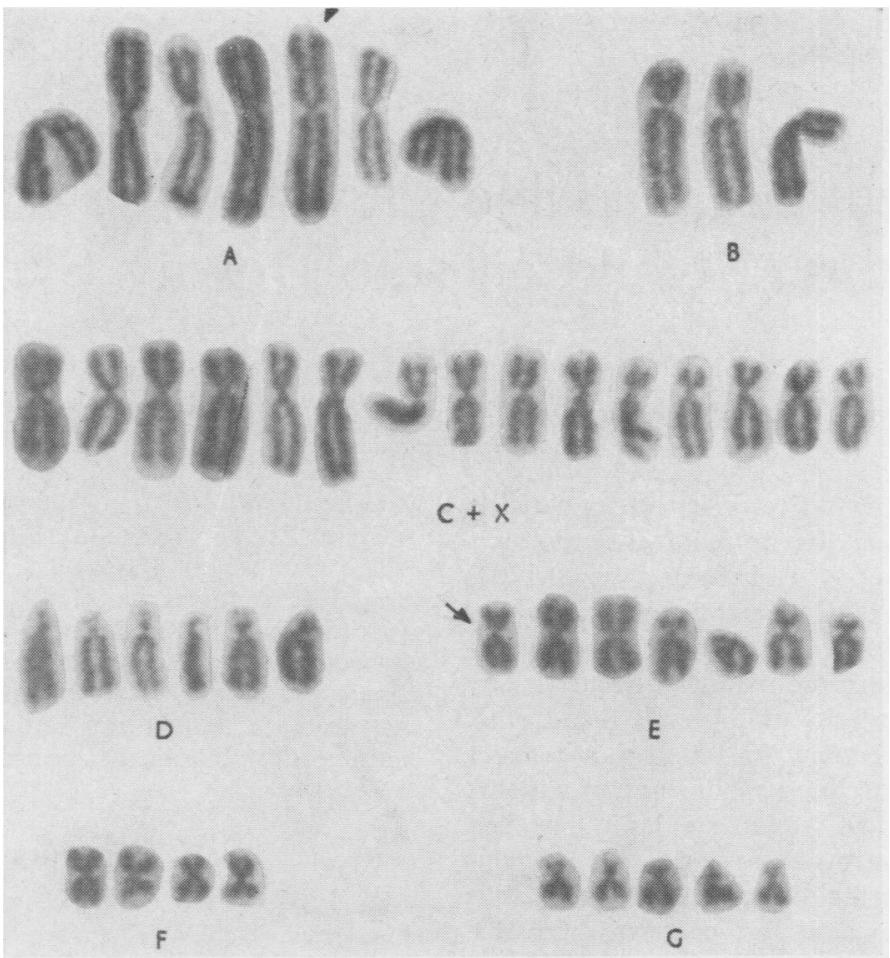

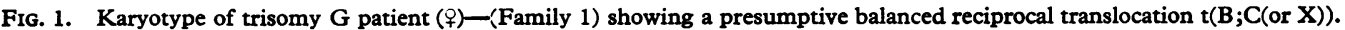
$47, \mathrm{XX}, \mathrm{G}+, \mathrm{t}(\mathrm{Bp}+; \mathrm{Cq}-)$ mat.

(ii) Variable chromosome anomalies. The number of chromatid breaks in patients and parents was similar. The only significant difference was a lower incidence of $\mathrm{C}_{\mathrm{u}}$ cells in female patients $(4 / 768)$ as compared to mothers $(27 / 1972 ; 0.02<$ $\mathrm{p}<0.05)$.

\section{(c) The Parents}

(i) Families with consistent chromosome anomalies. We examined the karyotypes of 85 mothers (47, Cowie, 1967) and 75 fathers (44, Cowie, 1967). Six families (Appendix Nos. 1, 4, 8, 25, 26, 95) showed heritable autosome anomalies and variations.

Family 1: The mother was the carrier (heterozygous) of the reciprocal balanced translocation (described in (b) above, for her daughter), 46,XX, $\mathrm{t}(\mathrm{Bp}+; \mathrm{Cq}-)$. The mother's and daughter's chromosome complements lacked one chromosome in each of groups B and C, but had two extra chromosomes, one resembling group $A$ and the other group E (Fig. 1 and 2).

Family 4: One D chromosome with abnormally prominent short arms was found in the mother but not her trisomic child (Fig. 3a).

Family 8: Dimorphism for chromosome 16 occurred in the mother and two of her children (one with Down's syndrome and one normal male sib) (Fig. 3b-d). In the mother both No. 16 chromosomes were large and one was more submedian than its pair. Both children had inherited the submedian chromosome 16.

Family 25: A satellited chromosome 17 was found in both husband and wife (Fig. 3e, f). When later interviewed, the couple stated that they both came from County Wexford in the Republic of Ireland but knew of no consanguinity between their families. The satellited chromosome was not detected in their trisomic child.

Family 26: The father, whose daughter was $46, X X, G-; t(G q G q)+$, carried an abnormal $G$ chromosome (Fig. 3g). It has been suggested that this was due to an $F / G$ reciprocal translocation (Cowie and Kahn, 1965); however, the more usual 


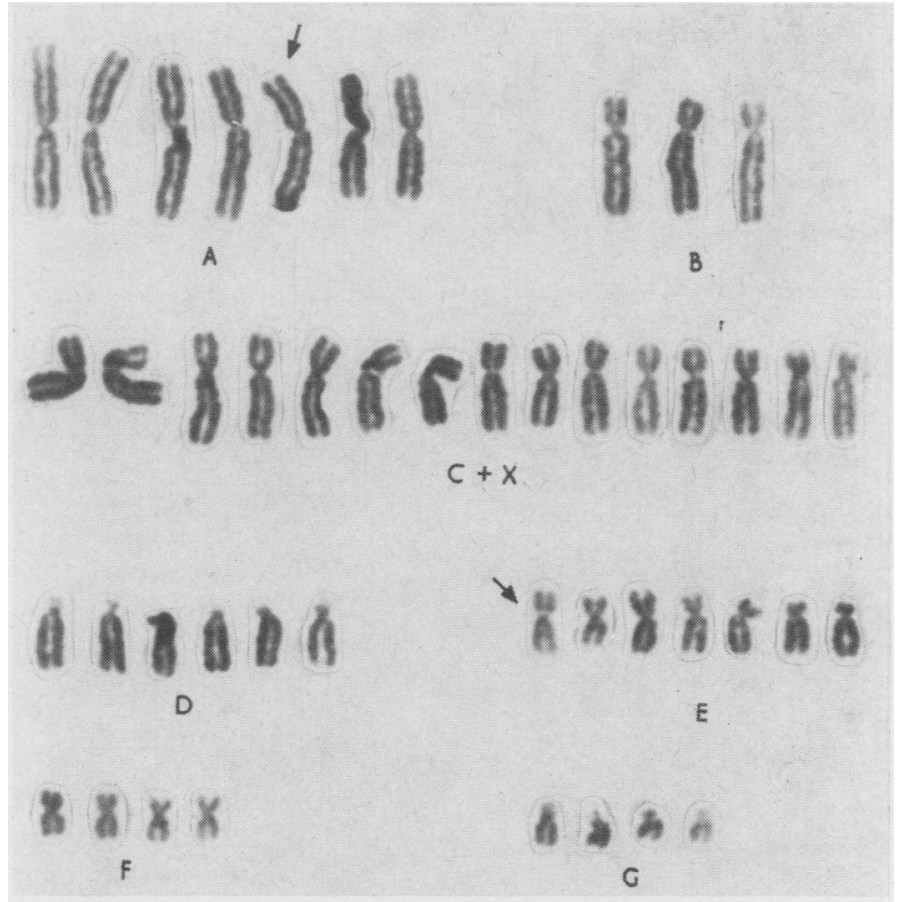

Fig. 2. Karyotype of mother (Family 1) carrying the presumptive balanced reciprocal translocation (shown in Fig. 1). 46. $\mathrm{XX}, \mathrm{t}(\mathrm{Bp}+$ $\mathrm{Cq}-$ ).

interpretation would be that it is an enlargement of the short arms of one $G$ group chromosome (Hamerton, 1965). The abnormal chromosome was also carried in one normal male child (Fig. $3 \mathrm{~h}$ ) but was absent in the patient.

Family 95: The mother had a $\mathrm{G}$ chromosome with enlarged short arms (Fig. 3j). The abnormal chromosome was absent in the patient.

(ii) Variable chromosome anomalies. These were classed into (a) structural anomalies, and (b) anomalies of chromosome number.

(a) The structural anomalies were classified in accordance with the Edinburgh survey into three categories:

(1) Cells with chromatid breaks (Fig. 3n). A broken chromosome with the two fragments still in the same cell was counted as one chromatid break. Chromatid gaps were not considered and therefore the term B cells was not used.

(2) $\mathrm{C}_{s}$-cells with either abnormal monocentric chromosomes or with an abnormal distribution of chromosomes within the subgroups (Fig. 4).
(3) $\mathrm{C}_{\mathrm{u}}$ cells, containing acentric fragments (Fig. $3 n)$.

(b) (1) Cells with 47 or 48 chromosomes were classed as hypermodal. Because of the difficulty in distinguishing broken cells from genuinely hypomodal cells, we did not include cells with 45 chromosomes among the total number of abnormal cells per sample (see Table III).

\section{Statistical Analysis of Data from Parents}

(a) Distribution of Maternal Age. Figures for maternal age distribution at the birth of a child with Down's syndrome were comparable in our series with those given by Penrose (1963), $0.5<\mathrm{p}<$ 0.7 ; this shows that our series was a random sample of Down's syndrome patients.

(b) Consistent Chromosome Anomalies. The Edinburgh survey showed that approximately 1 in 200 adults from the general population carried a balanced chromosome structural rearrangement with no apparent ill effect on health and development. We found one such case among 160 parents studied (Fig. 1).

The frequency among parents of our series of $\mathrm{D}$, 


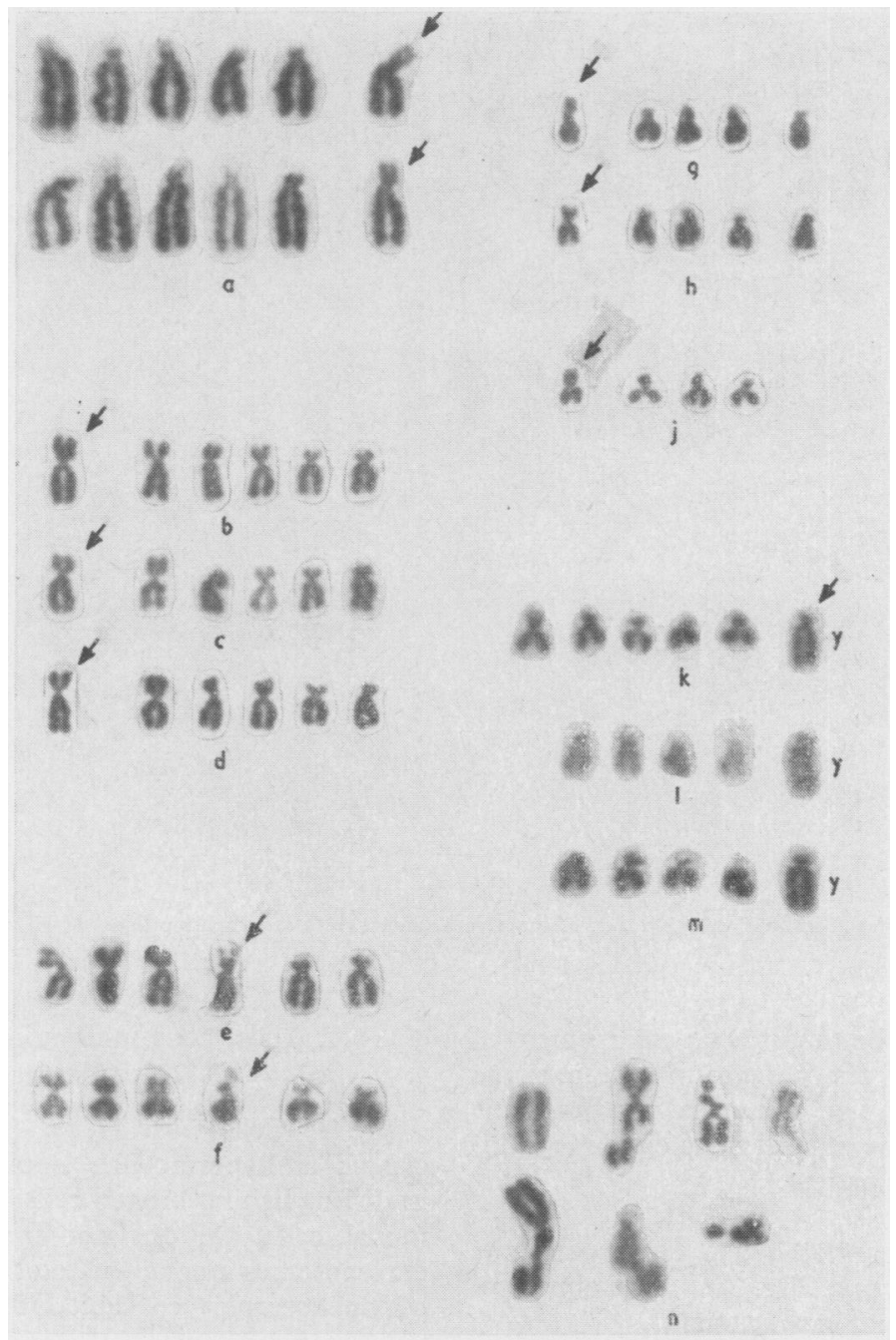

Fig. 3. Partial karyotypes showing consistent and variable anomalies: a, enlarged short arms of a $D$ chromosome in mother of patient (Family 4); b, c, d, dimorphism of chromosome pair 16 in mother, trisomy patient, and normal sib (Family 8); e, $f$, satellited chromosome 17 in husband and wife (Family 25); $\mathrm{g}, \mathrm{h}$, enlarged short arms of one $\mathrm{G}$ chromosome in father and normal sib'of patient (Family 26); j, enlarged short arms of $G$ chromosome in mother of patient (Family 95); $k, 1, m$, large $Y$ in patient, father, and uncle (Family 51); $\mathrm{n}$, examples of an acentric fragment and various chromatid breaks.

E, G, dimorphism (3.75\%) was also similar to that found in the Edinburgh survey $(2.25 \% ; 0.3<\mathrm{p}<$ $0 \cdot 4)$.

(c) Variable Chromosome Anomalies. The proportion of hypermodal cells in our series (15/3691) when compared with that of the Edinburgh data (20/3070), was not significant $(0 \cdot 11<$ p $<$ $0 \cdot 12)$. The number of hypomodal cells was lower in our series, $53 / 3691$ as against $88 / 3070$ in the Edinburgh survey. This could be due to fewer broken cells in our material. All differences be- tween the Edinburgh material and our own are discussed below.

Table I shows the frequency of cells with breakage anomalies in the parents of our series. Comparison is made with data in the corresponding age-groups of the Edinburgh survey. No significant difference is found between the total numbers of abnormal cells of the two surveys. The proportion of $\mathrm{C}_{8}$ cells is smaller in our series compared with that of the Edinburgh series and the difference is just significant.

The proportion of chromatid breaks was sig- 


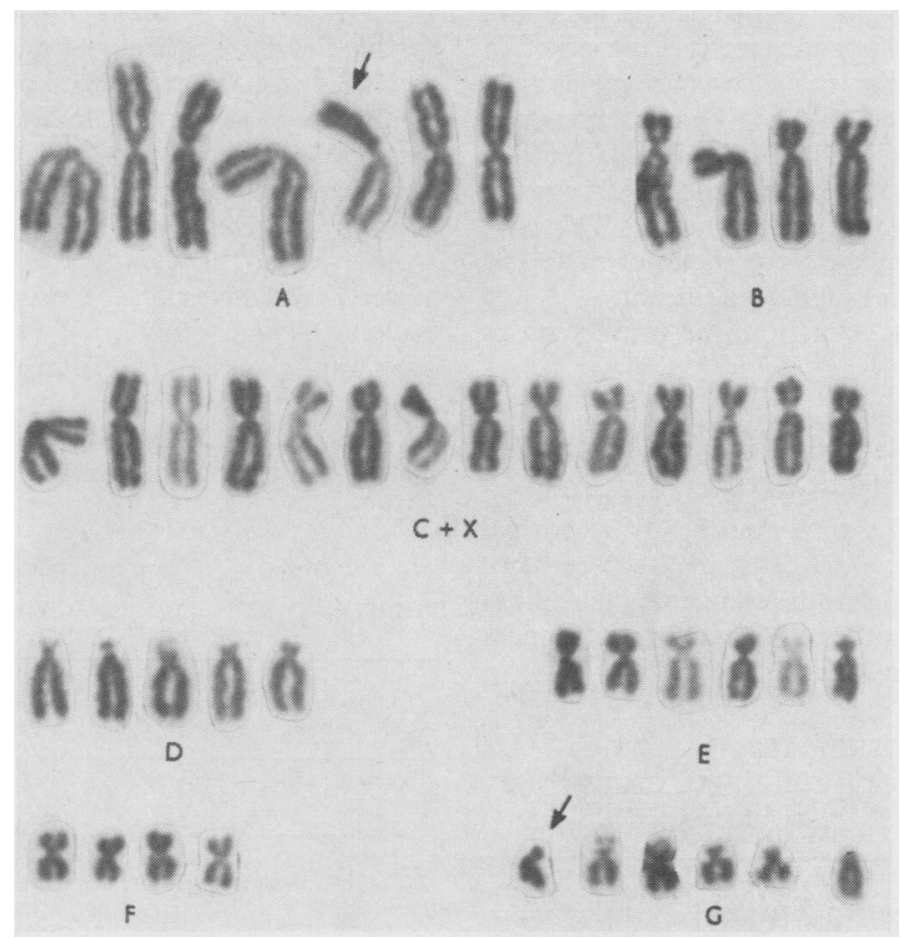

Fig. 4. Karyotype of a typical $\mathrm{C}_{s}$ cell (536F, Family 6). 46,XY,Cq-,t(CqDq)+.

TABLE I

FREQUENCY OF CELLS WITH STRUCTURAL ABNORMALITIES

\begin{tabular}{|c|c|c|c|}
\hline Cell Type & $\begin{array}{c}\text { Parents of } \\
\text { Mongols } \\
\text { Present } \\
\text { Series }\end{array}$ & $\begin{array}{c}\text { Court Brown } \\
\text { et al. (1966) } \\
\text { (Tables 10, 14, } \\
\text { XXX; XLV) }\end{array}$ & $\begin{array}{l}\text { Significance } \\
\text { Level of } \\
\text { Percentages }\end{array}$ \\
\hline $\begin{array}{l}\text { Cs male } \\
\text { Cs female } \\
\text { Cu male } \\
\text { Cu female } \\
\text { Chromatid breaks, } \\
\text { male } \\
\text { Chromatid breaks, } \\
\text { female } \\
\text { * Total-male } \\
\text { † Total-female }\end{array}$ & \begin{tabular}{|c|}
$8 / 1719$ \\
$8 / 1972$ \\
$9 / 1719$ \\
$27 / 1972$ \\
$21 / 1719$ \\
$(23 / 1719)$ \\
$29 / 1972$ \\
$(33 / 1972)$ \\
$38 / 1719$ \\
$63 / 1972$ \\
\end{tabular} & $\begin{array}{c}19 / 1784 \\
15 / 1286 \\
11 / 1784 \\
18 / 1286 \\
6 \text { or less } / 1784 \\
(7 / 1784) \\
4 \text { or less/1286 } \\
(5 / 1286) \\
36 / 1784 \\
37 / 1286\end{array}$ & $\begin{array}{c}0.04<\mathrm{p}<0.05 \\
0.01<\mathrm{p}<0.02 \\
\text { Not significant } \\
\text { Not significant } \\
\mathrm{p}<0.01 \\
(\mathrm{p}<0.01) \\
\mathrm{p}<0.01 \\
(\mathrm{p}<0.001) \\
\text { Not significant } \\
\text { Not significant }\end{array}$ \\
\hline
\end{tabular}

* aet 15-60, Parents of mongols present series, 15-64 Edinburgh survey.

$\dagger$ aet 15-49, Parents of mongols present series, 15-54 Edinburgh survey.

nificantly larger in our series. The difference became even more significant in females when we compared the two series with regard to number of chromatid breaks instead of number of cells with chromatid breaks; (these figures are given in brackets in the relevant sections of Table I).

Table II compares male and female data in each series. In our present series the only significant
TABLE II

FREQUENCY OF CELLS WITH STRUCTURAL ABNORMALITIES ; COMPARISON BETWEEN MALE AND FEMALE DATA IN EACH SERIES*

\begin{tabular}{|c|c|c|c|}
\hline Cell Type & Male & Female & $\begin{array}{l}\text { Significance } \\
\text { Level of } \\
\text { Percentages }\end{array}$ \\
\hline $\begin{array}{c}\text { Cs Parents of } \\
\text { mongols } \\
\text { present series } \\
\text { Cs Court } \\
\text { Brown et al. } \\
\text { (1966) } \\
\text { Cu Parents of } \\
\text { mongols } \\
\text { present series } \\
\text { Cu Court } \\
\text { Brown et al. } \\
\text { (1966) } \\
\text { Chromatid } \\
\text { breaks, } \\
\text { parents of } \\
\text { mongols } \\
\text { present series } \\
\text { Chromatid } \\
\text { breaks, Court } \\
\text { Brown et al. } \\
\text { (1966) } \\
\text { Total: } \\
\text { Parents of } \\
\text { mongols } \\
\text { present } \\
\text { series } \\
\text { Total: } \\
\text { Court } \\
\text { Brown et } \\
\text { al. (1966) }\end{array}$ & $\begin{array}{c}8 / 1719 \\
19 / 1784 \\
9 / 1719 \\
11 / 1784 \\
(47 / 4401)\end{array}$ & $\begin{array}{c}8 / 1972 \\
15 / 1286 \\
27 / 1972 \\
18 / 1286 \\
(82 / 4582)\end{array}$ & $\begin{array}{c}\text { Not significant } \\
\text { Not significant } \\
0.01<p<0.02 \\
0.02<p<0.03 \\
(p<0.01)\end{array}$ \\
\hline
\end{tabular}

\footnotetext{
$\star$ Data are the same as in Table I.
} 
difference is found in the frequencies of male and female $C_{u}$ cells. The significance is less marked in the Edinburgh survey when we compare males aged 15-64 with females aged 15-54. There is, however, a greater number of $C_{u}$ cells in the female sample. When we compare males and females of all ages in the Edinburgh survey (figures in brackets Table II) the difference between the frequencies of male and female $\mathrm{C}_{\mathrm{u}}$ cells becomes highly significant.

For further analysis data from the present series only were used.

\section{Distribution of Cells with Variable Anomalies in Present Series}

Table III shows the total number of abnormal cells, excluding hypomodal cells, in the parents of our series. No significant difference was found between fathers and mothers. Data for both sexes can accordingly be combined.

\section{TABLE III}

DISTRIBUTION OF ABNORMAL CELLS (EXCLUDING HYPOMODAL CELLS) FOUND IN FATHERS AND MOTHERS OF PRESENT SERIES

\begin{tabular}{c|r|r|r|r|r|r|c}
\hline Abnormal Cells/Sample & 0 & 1 & 2 & 3 & 4 & $\begin{array}{c}5 \\
\text { and } \\
\text { Over }\end{array}$ & $\begin{array}{c}\text { Total } \\
\text { Samples } \\
\text { Analysed }\end{array}$ \\
\hline $\begin{array}{c}\text { Fathers: No. of samples } \\
\text { Mothers: No. of samples }\end{array}$ & 55 & 10 & 6 & 3 & 2 & 1 & $\begin{array}{r}77 \\
89\end{array}$ \\
\hline Total & 112 & 19 & 17 & 12 & 4 & 2 & 166 \\
\hline
\end{tabular}

$x^{2}=3.55$, with 4 degrees of freedom (last two columns are combined), $0.7>p>0.5$.

A poisson distribution would be expected if the samples were taken from a single homogeneous population. The $\chi^{2}$ test shows a marked discrepancy between the observed and expected data (Table IV), and therefore the samples cannot be regarded as drawn from a homogeneous population with an even distribution of abnormal cells. The most likely alternative hypothesis is that, with regard to variable chromosome anomalies, our samples were drawn from a mixed population.

\section{TABLE IV}

COMPARISON BETWEEN OBSERVED DATA AND EXPECTED POISSON DISTRIBUTION

\begin{tabular}{c|c|c|c|c|c|c|c}
\hline $\begin{array}{c}\text { Abnormal } \\
\text { Cells } \\
\text { Sample }\end{array}$ & 0 & 1 & 2 & 3 & 4 & $\begin{array}{c}5 \\
\text { and } \\
\text { Over }\end{array}$ & Total \\
\hline $\begin{array}{c}\text { Observed } \\
\text { (male and } \\
\text { female) }\end{array}$ & 112 & 19 & 17 & 12 & 4 & 2 & 166 \\
\hline \begin{tabular}{c} 
Expected \\
\hline
\end{tabular}
\end{tabular}

$\chi^{2}=64 \cdot 7$, with 2 degrees of freedom (the last 3 columns are combined), $\mathrm{p}<0.0001$.
To test this hypothesis, it was necessary to derive a value for the frequency of negative samples which would be in conformity with a Poisson distribution of positive samples (Table V). This frequency of negative samples when calculated from the observed frequencies of positive samples resulted in a theoretical value of $10 \cdot 6$ (Fig. 5).

Analysis of the data in this light makes the observed frequencies fit the expected Poisson distribution $(0.95<\mathrm{p}<0.98)$. We may thus assume that our samples were drawn from a bimodal population, about one-third $65(64.6)$ of which contained an average of $2(1 \cdot 78)$ abnormal cells per sample; the rest of the population yielded $101(101.4)$ negative samples.

TABLE $\mathrm{V}$

POISSON DISTRIBUTION ACCORDING TO BIMODAL POPULATION HYPOTHESIS

\begin{tabular}{l|c|c|c|c|c|c|c}
\hline $\begin{array}{c}\text { Abnormal } \\
\text { Cells/Sample }\end{array}$ & 0 & 1 & 2 & 3 & 4 & $\begin{array}{c}5 \\
\text { and } \\
\text { Over }\end{array}$ & Total \\
\hline $\begin{array}{l}\text { Observed } \\
\text { Expected }\end{array}$ & $\begin{array}{c}(10.6) \\
10.9\end{array}$ & $\begin{array}{l}19 \\
19 \cdot 3\end{array}$ & $\begin{array}{l}17 \\
17 \cdot 2\end{array}$ & $10 \cdot 2$ & 4.6 & 2.4 & 64.6 \\
\hline
\end{tabular}

$\chi^{2}=0.47$ with 4 degrees of freedom, $0.98>p>0.95$.

The expected frequencies were calculated from the following formula:

$$
f(x)=N \frac{e^{-m} \mathbf{m} x}{x !}
$$

where $\mathrm{N}$ is the number of samples in question (here 64.6), $x$ the number of abnormal cells, and $m$ the mean abnormal cells per sample (of the affected population), which was found to be 1.78.

The figure in the first column of the first row in parentheses was calculated from the frequencies for 1-5 abnormal cells (frequencies of the first row).

\section{Discussion}

In culturing blood samples from families with Down's syndrome our original aim was to distinguish between subjects with primary trisomy and those with translocations. Because of this no planned control series of the general population was cultured at the same time. Comparison with a small series of cultures referred to us for other reasons (during the same period) showed that the high incidence of chromatid breakage was unique to families in which Down's syndrome had occurred. Nevertheless, in the absence of a planned control series it is desirable to consider (1) whether or not there are significant differences between the batches of cultures in our Down's syndrome series; (2) whether the differences between our series and the Edinburgh survey, which were qualitative rather than quantitative, were due to a difference in the handling of cultures and the final scoring of cell types.

Our culture records show (Appendix) that on 25 occasions a sample from an 'affected' parent was 


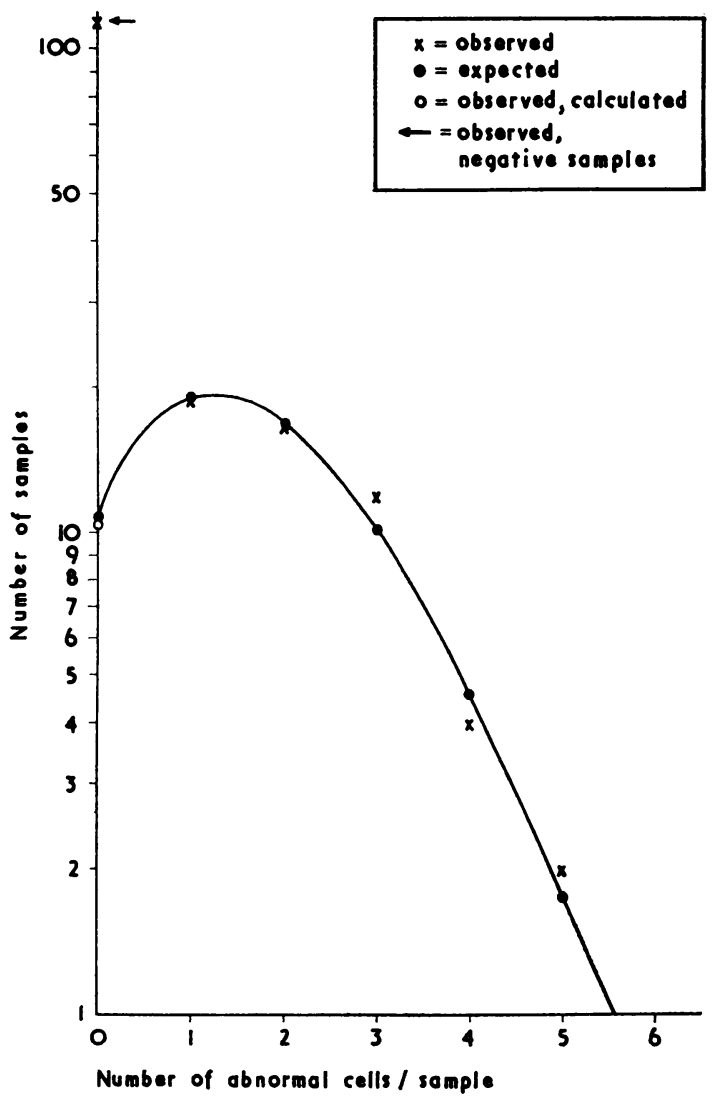

Fig. 5. Poisson distribution according to a bimodal population hypothesis (Table V).

cultured at the same time as the sample from his or her 'unaffected' spouse. On only two occasions both parents were affected. This implies that the cell abnormalities found were not due to accidents of handling or infection varying from one batch of cultures to another. We may note moreover the many similarities between our series and the Edinburgh survey (Tables I, II). There was no significant difference between total numbers of abnormal cells. There was neither a difference between frequencies of $\mathrm{C}_{\mathrm{u}}$ cells nor of hypermodal cells. Comparison between male and female data within each series yielded comparable results; even to the extent that both populations show a significant increase in the number of $C_{u}$ cells among females when compared with males. Among patients with Down's syndrome and their parents the only difference is found in the distribution of $\mathrm{C}_{\mathrm{u}}$ cells among females. Significantly fewer $C_{u}$ cells were recorded in female patients than in their mothers. The frequency of $\mathrm{C}_{\mathrm{u}}$ cells was similar in male and female patients and their fathers. This suggests that whereas the distribution of $\mathrm{C}_{u}$ cells in males is similar for all ages, their frequency increases with advancing age in females. This is compatible with data in Table II, where it is shown that with the advancing age of the Edinburgh population significantly more $C_{u}$ cells were found in females than in males. It is an aspect which should be further investigated.

We are thus left with the question of compatibility in the scoring of cell types. Compared with the Edinburgh survey we find in our series too many chromatid breaks and too few $\mathrm{C}_{\mathrm{s}}$ cells. However, of the cells scored as containing chromatid breaks none had structural changes other than (a) single or iso-chromatid breaks, (b) chromatid interchanges ( 2 cells); neither of these cell types would qualify for the 'Edinburgh' definition of $\mathrm{C}_{s}$ cells, which states (p. 35), ' $\mathrm{C}_{\mathrm{s}}$ cells contain either obviously abnormal monocentric chromosomes or have an abnormal distribution of chromosomes within the recognised subgroups'. It may therefore be assumed that the differences between the parents of the present series and the general population of the Edinburgh survey were real and were not due to a difference in the handling of cultures or the final scoring of cell types. This interpretation was confirmed by the fact that the incidence of chromatid breakage $(0.38 \%)$ in our series of families with no Down's syndrome resembled that of the Edinburgh survey $(0.42 \%)$.

The individuals investigated in the present study represent a non-random sample of the general population because they were parents of children with Down's syndrome, and it is possible that this fact may also account for cytogenetic differences between this series and the Edinburgh survey.

There is no evidence that the incidence of breakage was higher in parents of mongols compared to the Edinburgh population. The ratios $\mathbf{C}_{\mathrm{s}}$ cells/ chromatid breaks were inversely proportional in the two populations. The question can therefore be raised, whether an increase in the number of chromatid breaks is related to a reduction in the number of $\mathrm{C}_{s}$ cells. This discrepancy between the two populations could be accounted for on the basis of Revell's exchange hypothesis (Revell, 1955) which postulates that a visible chromatid break may be due to incomplete intrachange of an isochromatid break. Similarly some of the $\mathrm{C}_{\mathrm{s}}$ cells could be interpreted as complete intrachanges. Therefore it seems possible that a partial failure of the repair mechanism of breakage could have been involved in the production of a larger number of visible chromatid breaks in parents of mongols. According to the 
classical interpretation of chromosome aberrations, chromatid breakage in our cultures should have been induced mainly during the $G_{2}$ period of the cell cycle. Since our blood samples were collected and cultured over a long period of time and since mitoses were not synchronous, specific timing of breakage would in itself be an expression of an inherent difference between the two populations discussed in this study. Alternatively, this inherent difference could be explained again as a partial failure to repair chromosome or chromatid breaks, in our present series of parents of children with Down's syndrome.

Future work including controls should consider the possibility of an experimental approach, i.e. the scoring of chromatid reunion (not restitution) after in vitro induction of breakage, as was done on roottip cells of Vicia faba (Revell, 1959; Evans, 1962). In this way our hypothesis could be further tested.

Our results were obtained from short-term cultures of lymphocytes; we therefore do not suggest that chromatid breakage leads to increased frequency of non-disjunction. Instead it is thought possible that cells from our population sample, when compared with cells from the Edinburgh series, were more sensitive to external factors, such as radiation, viruses, or in vitro culturing.

\section{Summary}

In this chromosome study 75 fathers and 85 mothers of children with Down's syndrome were examined. The results were compared with data from the general population of Edinburgh (Court Brown et al., 1966).

The present series contained significantly more chromatid breaks; at the same time significantly fewer cells with presumptive stable chromosome rearrangements were found $\left(C_{s}\right.$ cells $)$. This suggests an impairment to the repair mechanism of chromatid breakage. In all other respects the two population samples yielded comparable results. Thus, for example, the number of cells with unstable chromosome rearrangements $\left(\mathrm{C}_{\mathrm{u}}\right.$ cells) was similar in the two populations. Analysis also showed a significantly higher incidence of $\mathrm{C}_{u}$ cells among females of both populations.

A significant difference was also found in the incidence of chromatid breakage between the Down's syndrome series $(1.25 \%)$ and other cases $(0.38 \%)$ investigated during the same period in this laboratory. This suggests that the differences between the Edinburgh survey and the Down's syndrome series were not due to technical artefacts. The results were obtained from short-term cultures of lymphocytes, and it is not thought that the increase in chromatid breakage leads to an increased frequency of non-disjunction. Instead, it is thought possible that cells from the present population sample, when compared with cells from the Edinburgh series, were more sensitive to external factors such as radiation, viruses, or in vitro culturing.

In the course of this study we have benefited from the experience and skill of other workers. In particular we wish to thank Dr. V. A. Cowie for constant advice and encouragement. Numerous discussions with Dr. V. A. Cowie, Dr. J. L. Hamerton, and Dr. E. T. O. Slater have enriched the scope of our paper. We owe a debt of gratitude to the many family doctors and consultants who allowed access to their patients. In particular we would like to thank Dr. J. H. Burkinshaw, Dr. J. N. O'Reilly, and Dr. C. E. Stroud. Mr. N. Dernley's skilful handling of the cultures greatly facilitated the microscopical analysis. Last but not least we wish to thank all those parents who agreed to co-operate.

\section{REFERENCES}

Court Brown, W. M., Buckton, K. E., Jacobs, P. A., and Tough, I. M. (1966). Chromosome Studies on Adults. Cambridge University Press, London.

Cowie, V. A. (1967). A study of the development of mongols from a general population sample. Ph.D. dissertation, University of London.

- and Kahn, J. (1965). A mongol child without trisomy G. Lancet, 2, 58.

Evans, E. P., Breckon, G., and Ford, C. E. (1964). An air drying method for meiotic preparation from mammalian testes. Cytogenetics, 3, 289.

Evans, H. J. (1962). Chromosome aberrations induced by ionizing radiations. Int. Rev. Cytol., 13, 221.

Hamerton, J. L. (1965). A mongol child without trisomy G. Lancet, 2, 186.

Moorhead, P. S., Nowell, P. C., Mellman, W. J., Batipps, D. M., and Hungerford, D. A. (1960). Chromosome preparations of leukocytes cultured from human peripheral blood. Exp. Cell Res., 20, 613.

Penrose, L. S. (1963). The Biology of Mental Defect, 3rd ed. Sidgwick and Jackson, London.

Revell, S. H. (1955). A new hypothesis for chromatid changes. In Proceedings of the Radiobiology Symposium, Liege, p. 243. Ed. by Z. M. Bacq and P. Alexander. Butterworth, London.

(1959). The accurate estimation of chromatid breakage, and its relevance to a new interpretation of chromatid aberrations induced by ionizing radiations. Proc. roy. Soc. B, 150, 563. 
APPENDIX

\begin{tabular}{|c|c|c|c|c|c|c|c|c|c|c|}
\hline \multirow{2}{*}{$\begin{array}{l}\text { Family No. } \\
\text { and Date of } \\
\text { Culture }\end{array}$} & \multirow{2}{*}{$\begin{array}{l}\text { Culture } \\
\text { Refer- } \\
\text { ence }\end{array}$} & \multirow[t]{2}{*}{ Status } & \multirow[t]{2}{*}{ Analysis ${ }^{\star \star}$} & \multicolumn{5}{|c|}{$\begin{array}{c}\text { Distribution } \\
\text { of } \\
\text { Chromosome Counts }\end{array}$} & \multirow{2}{*}{$\begin{array}{l}\text { Total No. } \\
\text { of Cells } \\
\text { Analysed }\end{array}$} & \multirow{2}{*}{$\begin{array}{l}\text { No. of Cells } \\
\text { With } \\
\text { Variable } \\
\text { Anomalies }\end{array}$} \\
\hline & & & & $<45$ & 45 & $\mid 46$ & 47 & $>47$ & & \\
\hline 1. $\begin{array}{r}21.10 .65 \\
4.8 .64 \\
4.8 .64\end{array}$ & $\begin{array}{r}283 \\
4 \\
3\end{array}$ & $\begin{array}{l}\mathrm{P} \\
\mathrm{M} \\
\mathrm{F}\end{array}$ & $\begin{array}{l}47, \mathrm{XX}, \mathrm{G}+, \mathrm{t}(\mathrm{Bp}+; \mathrm{Cq}-) \\
46, \mathrm{XX}, \mathrm{t}(\mathrm{Bp}+; \mathrm{Cq}-) \\
46, \mathrm{XY}\end{array}$ & 1 & 1 & $\begin{array}{l}38 \\
18\end{array}$ & $\begin{array}{r}19 \\
2\end{array}$ & 1 & $\begin{array}{l}20 \\
40 \\
18\end{array}$ & $\begin{array}{l}1 \mathrm{Cu}_{\mathrm{u}} \\
2 \mathrm{Cu} ; 2 \text { brks } \\
\text { 1brk }\end{array}$ \\
\hline $\begin{array}{l}1.2 .65 \\
2 . \\
1.2 .65 \\
1.2 .65\end{array}$ & $\begin{array}{l}142 \\
144 \\
143\end{array}$ & $\begin{array}{l}\mathrm{P} \\
\stackrel{M}{F}\end{array}$ & $\begin{array}{l}\text { 47,XX, }, \mathrm{X}+ \\
46, \mathrm{XX} \\
46, \mathrm{XY}\end{array}$ & & & $\begin{array}{l}48 \\
20\end{array}$ & $\begin{array}{r}20 \\
2\end{array}$ & 1 & $\begin{array}{l}20 \\
50 \\
20\end{array}$ & $2 \mathrm{C}_{\mathrm{u}} ; 2(47)$ \\
\hline 3. $\begin{array}{r}15.12 .64 \\
11.1 .66\end{array}$ & $\begin{array}{l}109 \\
293\end{array}$ & $\begin{array}{l}\mathbf{P} \\
\mathbf{F}\end{array}$ & $\begin{array}{l}47, \mathbf{X X}, G+ \\
46, \mathbf{X Y}\end{array}$ & & & $\begin{array}{r}1 \\
20 \\
\end{array}$ & 18 & 1 & $\begin{array}{l}20 \\
20\end{array}$ & $\begin{array}{l}1 \mathrm{C}_{\mathrm{u}} \text {; 1brk } \\
\text { 2brks }\end{array}$ \\
\hline $\begin{array}{rr} & 4.12 .64 \\
4 . \quad 4.12 .64 \\
\end{array}$ & $\begin{array}{l}97 \\
99 \\
98\end{array}$ & $\begin{array}{l}\mathrm{P} \\
\mathrm{M} \\
\mathrm{F}\end{array}$ & $\begin{array}{l}\text { 47,XY,G+ } \\
46, \mathrm{XX}, \mathrm{Dp}+ \\
46, \mathrm{XY} \\
\end{array}$ & & & $\begin{array}{l}20 \\
30 \\
\end{array}$ & 20 & & $\begin{array}{l}20 \\
20 \\
30\end{array}$ & 2brks \\
\hline $\begin{array}{lr}\text { 5. } & 13.4 .66 \\
\end{array}$ & $\begin{array}{l}506 \mathrm{C} \\
506 \mathrm{M}\end{array}$ & $\stackrel{P}{M}$ & $\begin{array}{l}47, \mathrm{XY}, \mathrm{G}+ \\
46, \mathrm{XX}\end{array}$ & & & 20 & 20 & & $\begin{array}{l}20 \\
20\end{array}$ & \\
\hline $\begin{array}{lr} & 23.8 .66 \\
6 . & 23.8 .66 \\
23.8 .66\end{array}$ & $\begin{array}{l}536 \mathrm{C} \\
536 \mathrm{M} \\
536 \mathrm{~F}\end{array}$ & $\begin{array}{l}\mathbf{P} \\
\mathbf{M} \\
\mathrm{F}\end{array}$ & $\begin{array}{l}47, X X, G+ \\
46, X X \\
46, X Y\end{array}$ & & 4 & $\begin{array}{l}10 \\
57\end{array}$ & 10 & & $\begin{array}{l}10 \\
10 \\
30 \\
30\end{array}$ & $2 C_{s} ; 1 C_{u} ; 4 b r k s$ \\
\hline $\begin{array}{rr}10.11 .64 \\
\text { 7. } & 10.11 .64 \\
23.8 .65 \\
\end{array}$ & $\begin{array}{r}75 \\
74 \\
255 \\
\end{array}$ & $\begin{array}{l}\mathbf{P} \\
\mathbf{M} \\
\mathbf{F}\end{array}$ & $\begin{array}{l}47, X Y, G+ \\
46, X X \\
46, X Y\end{array}$ & & $\begin{array}{l}2 \\
1\end{array}$ & $\begin{array}{r}1 \\
19 \\
60 \\
\end{array}$ & $\begin{array}{r}19 \\
1\end{array}$ & $\begin{array}{l}1 \\
1\end{array}$ & $\begin{array}{l}20 \\
20 \\
60\end{array}$ & $1(47) ; 1 C_{u} ; 1$ brk \\
\hline $\begin{array}{ll} & 9.8 .66 \\
\star 8 . & 9.8 .66 \\
& 9.8 .66 \\
\end{array}$ & \begin{tabular}{|l|}
$532 \mathrm{C}$ \\
$532 \mathrm{M}$ \\
$532 \mathrm{~F}$
\end{tabular} & $\begin{array}{l}\mathbf{P} \\
\mathrm{M} \\
\mathrm{F}\end{array}$ & $\begin{array}{l}\text { 47,XX,G +, 16dim,mat. } \\
\text { 46,XX,16dim } \\
46, \mathrm{XY}\end{array}$ & & & $\begin{array}{l}10 \\
10 \\
\end{array}$ & 10 & & $\begin{array}{l}10 \\
10 \\
10 \\
\end{array}$ & 1 brk \\
\hline $\begin{array}{r}8.12 .64 \\
9 . \quad 6.5 .65 \\
6.5 .65 \\
\end{array}$ & $\begin{array}{l}103 \\
198 \\
197\end{array}$ & $\begin{array}{l}\mathbf{P} \\
\mathbf{M}\end{array}$ & $\begin{array}{l}47, \mathrm{XY}, \mathrm{G}+ \\
46, \mathrm{XX} \\
46, \mathrm{XY}\end{array}$ & & 1 & $\begin{array}{l}20 \\
19 \\
\end{array}$ & $\begin{array}{r}20 \\
1 \\
\end{array}$ & 2 & $\begin{array}{l}20 \\
20 \\
20\end{array}$ & $\begin{array}{l}3 \text { brks } \\
1(47)\end{array}$ \\
\hline 10. $\begin{array}{r}17.11 .64 \\
26.11 .65 \\
17.11 .64 \\
\end{array}$ & $\begin{array}{r}79 \\
139 \\
80\end{array}$ & $\begin{array}{l}\mathrm{P} \\
\mathrm{M} \\
\mathrm{F}\end{array}$ & $\begin{array}{l}\text { 47,XX, G } \\
46, \mathrm{XX} \\
46, \mathrm{XY}\end{array}$ & & 1 & \begin{tabular}{|l|}
30 \\
20 \\
\end{tabular} & $\begin{array}{r}20 \\
1\end{array}$ & & $\begin{array}{l}20 \\
30 \\
20 \\
\end{array}$ & \\
\hline 11. $\begin{array}{r}25.10 .65 \\
25.10 .65 \\
25.10 .65\end{array}$ & $\begin{array}{l}288 \\
287 \\
286\end{array}$ & $\begin{array}{l}\mathrm{P} \\
\mathrm{M}\end{array}$ & $\begin{array}{l}46, \mathrm{XX}, \mathrm{t}(\mathrm{GqGq})+ \\
46, \mathrm{XX} \\
46, \mathrm{XY}\end{array}$ & & $\begin{array}{l}1 \\
5\end{array}$ & \begin{tabular}{|l|}
20 \\
20 \\
54 \\
\end{tabular} & & & $\begin{array}{l}20 \\
20 \\
59\end{array}$ & $\begin{array}{l}\text { lbrk } \\
\text { lbrk; } 4 C_{s}\end{array}$ \\
\hline 12. 14.12 .64 & 108 & $\mathbf{P}$ & $47, \mathrm{XY}, \mathrm{G}+$ & & & 1 & 19 & & 20 & 2brks \\
\hline $\begin{array}{lr}13 . & 22.2 .65 \\
22.2 .65\end{array}$ & $\begin{array}{l}162 \\
161\end{array}$ & $\stackrel{P}{M}$ & $\begin{array}{l}47, \mathrm{XY}, \mathrm{G}+ \\
46, \mathrm{XX}\end{array}$ & 1 & & 59 & 40 & 3 & $\begin{array}{l}20 \\
60\end{array}$ & lbrk; $1(48)$ \\
\hline $\begin{array}{ll}14 . & 3.5 .65 \\
\end{array}$ & $\begin{array}{l}195 \\
194\end{array}$ & $\begin{array}{l}\mathrm{M} \\
\mathrm{F}\end{array}$ & $\begin{array}{l}46, X X \\
46, X Y\end{array}$ & & & \begin{tabular}{|l|}
20 \\
20
\end{tabular} & & & $\begin{array}{l}20 \\
20\end{array}$ & \\
\hline †15. $\begin{array}{r}11.10 .66 \\
11.10 .66 \\
11.10 .66\end{array}$ & \begin{tabular}{|l|}
$545 \mathrm{C}$ \\
$545 \mathrm{M}$ \\
$545 \mathrm{~F}$
\end{tabular} & $\begin{array}{l}\mathrm{P} \\
\mathrm{M} \\
\mathrm{F}\end{array}$ & $\begin{array}{l}47, \mathrm{XX}, \mathrm{G}+ \\
46, \mathrm{XX} \\
46, \mathrm{XY}\end{array}$ & & & $\begin{array}{l}10 \\
10 \\
\end{array}$ & 10 & & $\begin{array}{l}10 \\
10 \\
10\end{array}$ & 3brks \\
\hline $\begin{array}{rr}23.4 .65 \\
16 . & 23.4 .65 \\
\end{array}$ & $\begin{array}{l}186 \\
185 \\
\end{array}$ & $\begin{array}{l}\mathrm{P} \\
M\end{array}$ & $\begin{array}{l}47, \mathrm{XX}, \mathrm{G}+ \\
46, \mathrm{XX}\end{array}$ & & & 20 & 20 & & $\begin{array}{l}20 \\
20\end{array}$ & $2 \mathrm{Cu}_{\mathrm{u}}$ \\
\hline 17. $\quad 5.11 .64$ & 70 & $\mathbf{P}$ & $47, \mathrm{XX}, \mathrm{G}+$ & & & 1 & 19 & & 20 & \\
\hline $\begin{array}{r}3.6 .66 \\
18 . \\
3.6 .66 \\
\quad 3.6 .66 \\
\end{array}$ & $\begin{array}{l}512 \mathrm{C} \\
512 \mathrm{M} \\
512 \mathrm{~F} \\
\end{array}$ & $\begin{array}{l}\mathrm{P} \\
\mathrm{M} \\
\mathrm{F}\end{array}$ & $\begin{array}{l}\text { 47,XX, }, \mathrm{X}+ \\
46 \mathrm{XX} \\
46, \mathrm{XY}\end{array}$ & $\begin{array}{l}1 \\
1\end{array}$ & & $\begin{array}{l}20 \\
19 \\
\end{array}$ & 20 & & $\begin{array}{l}20 \\
20 \\
20\end{array}$ & \\
\hline $\begin{array}{rr} & 4.8 .64 \\
19 . & 17.8 .64 \\
& 17.8 .64 \\
\end{array}$ & $\begin{array}{r}6 \\
11 \\
10 \\
\end{array}$ & $\begin{array}{l}\mathbf{P} \\
\mathbf{M} \\
\mathbf{F}\end{array}$ & $\begin{array}{l}\text { 47,XX, }, \mathbf{X}+ \\
46 \mathrm{X} \times \\
46, \mathbf{X Y}\end{array}$ & 1 & 3 & $\begin{array}{l}1 \\
35 \\
49 \\
\end{array}$ & $\begin{array}{r}19 \\
1 \\
\end{array}$ & & $\begin{array}{l}20 \\
35 \\
50\end{array}$ & $1(47)$ \\
\hline 20. $\quad 11.12 .64$ & 106 & $\mathbf{P}$ & $47, X X, G+$ & & & & 20 & & 20 & \\
\hline $\begin{array}{r}13.10 .64 \\
21 . \\
22.10 .64 \\
6.11 .64 \\
\end{array}$ & $\begin{array}{l}50 \\
57 \\
73\end{array}$ & $\begin{array}{l}\mathrm{P} \\
\mathrm{M} \\
\mathrm{F}\end{array}$ & $\begin{array}{l}\text { 47,XX,G+ } \\
46, \mathrm{XX} \\
46, \mathrm{XY}\end{array}$ & & & $\begin{array}{l}20 \\
15\end{array}$ & 20 & & $\begin{array}{l}20 \\
20 \\
15\end{array}$ & \\
\hline $\begin{array}{ll} & 15.6 .65 \\
22 . & 15.6 .65 \\
29.6 .65\end{array}$ & $\begin{array}{l}223 \\
222 \\
230\end{array}$ & $\begin{array}{l}\mathrm{P} \\
\mathrm{M} \\
\mathrm{F}\end{array}$ & $\begin{array}{l}47, \mathrm{XY}, \mathrm{G}+ \\
46, \mathrm{XX} \\
46, \mathrm{XY}\end{array}$ & & & $\begin{array}{l}20 \\
45\end{array}$ & 10 & & $\begin{array}{l}10 \\
20 \\
25 \\
20\end{array}$ & $1 C_{s} ; 1 C_{u}$ \\
\hline $\begin{array}{rr} & 3.11 .64 \\
23 . & 6.8 .65 \\
& 6.8 .65\end{array}$ & $\begin{array}{r}68 \\
245 \\
244\end{array}$ & $\begin{array}{l}\mathrm{P} \\
\mathrm{M}\end{array}$ & $\begin{array}{l}\text { 47,XY, G+ }+ \\
46, \mathrm{XX} \\
46, \mathrm{XY}\end{array}$ & 1 & 2 & $\begin{array}{l}36 \\
40\end{array}$ & 20 & 1 & $\begin{array}{l}20 \\
36 \\
40\end{array}$ & $1 \mathrm{C}_{\mathrm{u}} ; 2 \mathrm{brks}$ \\
\hline
\end{tabular}


APPENDIX-continued

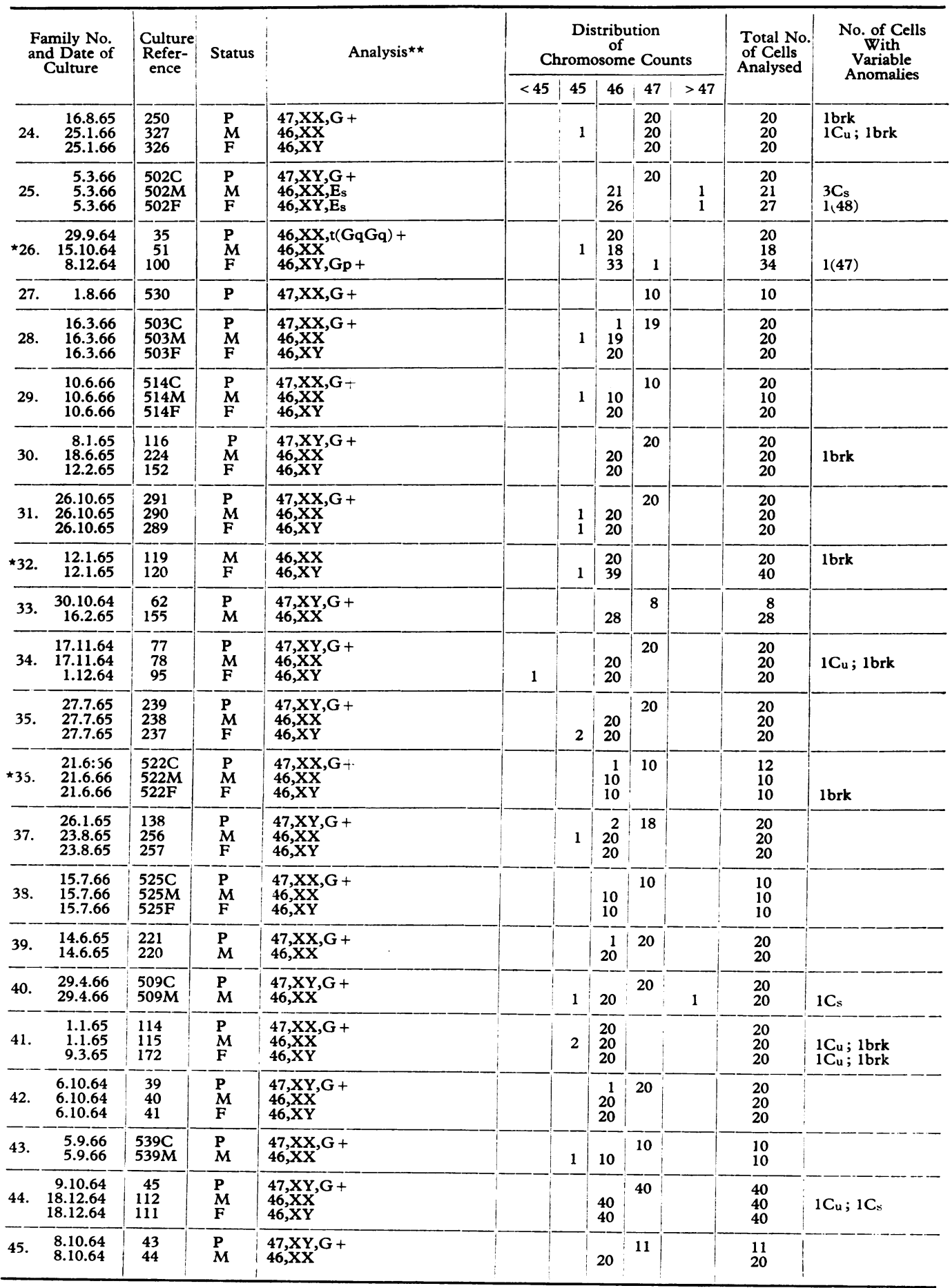


APPENDIX-continued

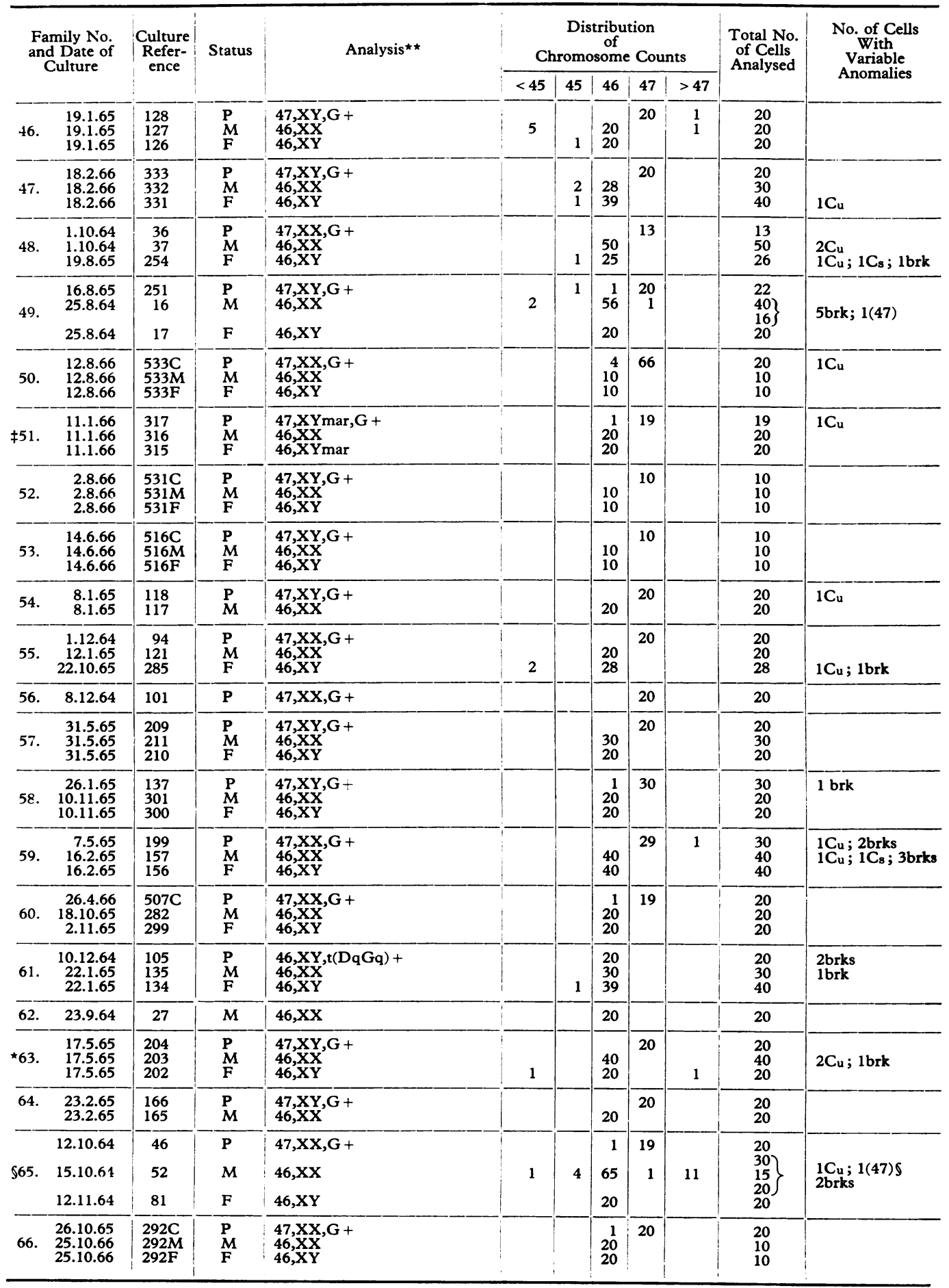


Kahn and Abe

APPENDIX-continued

\begin{tabular}{|c|c|c|c|c|c|c|c|c|c|c|}
\hline \multirow{2}{*}{$\begin{array}{l}\text { Family No. } \\
\text { and Date of } \\
\text { Culture }\end{array}$} & \multirow{2}{*}{$\begin{array}{l}\text { Culture } \\
\text { Refer- } \\
\text { ence }\end{array}$} & \multirow[t]{2}{*}{ Status } & \multirow[t]{2}{*}{ Analysis $\star \star$} & \multicolumn{5}{|c|}{$\begin{array}{c}\begin{array}{c}\text { Distribution } \\
\text { of } \\
\text { Chromosome Counts }\end{array} \\
\end{array}$} & \multirow{2}{*}{$\begin{array}{c}\text { Total No. } \\
\text { of Cells } \\
\text { Analysed }\end{array}$} & \multirow{2}{*}{$\begin{array}{c}\text { No. of Cells } \\
\text { With } \\
\text { Variable } \\
\text { Anomalies }\end{array}$} \\
\hline & & & & $<45$ & 45 & 46 & 47 & $>47$ & & \\
\hline $\begin{array}{r}29.10 .65 \\
67.10 .65 \\
29.10 .65 \\
\end{array}$ & $\begin{array}{l}296 \\
295 \\
294 \\
\end{array}$ & $\begin{array}{l}\mathrm{P} \\
\mathbf{M} \\
\mathrm{F}\end{array}$ & $\begin{array}{l}47, \mathrm{XX}, \mathrm{G}+ \\
46, \mathrm{XX} \\
46, \mathrm{XY} \\
\end{array}$ & 1 & & $\begin{array}{r}1 \\
30 \\
30 \\
\end{array}$ & 20 & & $\begin{array}{l}20 \\
30 \\
30 \\
\end{array}$ & $3 C_{u}$ \\
\hline $\begin{array}{r}27.10 .64 \\
68.2 .65 \\
23.3 .65 \\
\end{array}$ & $\begin{array}{r}60 \\
147 \\
178 \\
\end{array}$ & $\begin{array}{l}\mathbf{P} \\
\mathbf{M} \\
\mathbf{F}\end{array}$ & $\begin{array}{l}\text { 47,XX,G }+ \\
46, \mathrm{XX} \\
46, \mathrm{XY}\end{array}$ & & 1 & $\begin{array}{l}18 \\
30 \\
\end{array}$ & $\begin{array}{r}20 \\
2\end{array}$ & & $\begin{array}{l}20 \\
20 \\
30\end{array}$ & $2 \mathrm{Cu}_{\mathrm{u}}$ \\
\hline $\begin{array}{r}26.10 .64 \\
69.11 .64 \\
10.8 .65\end{array}$ & $\begin{array}{r}59 \\
93 \\
249\end{array}$ & $\begin{array}{l}\mathrm{P} \\
\mathrm{M} \\
\mathrm{F}\end{array}$ & $\begin{array}{l}47, \mathrm{XY}, \mathrm{G}+ \\
46, \mathrm{XX} \\
46, \mathrm{XY}\end{array}$ & & 1 & $\begin{array}{l}48 \\
20\end{array}$ & $\begin{array}{r}20 \\
2\end{array}$ & & $\left.\begin{array}{l}20 \\
20 \\
30 \\
20\end{array}\right\}$ & $\begin{array}{l}1 C_{u} ; 1 \text { brk } \\
1 C_{u} ; 1 C_{s} \\
2(47)\end{array}$ \\
\hline $\begin{array}{rr} & 23.9 .66 \\
70 . \quad 23.9 .66 \\
\end{array}$ & $\begin{array}{l}542 \mathrm{C} \\
542 \mathrm{M} \\
542 \mathrm{~F} \\
\end{array}$ & $\begin{array}{l}\mathbf{P} \\
\mathbf{M} \\
\mathbf{F} \\
\end{array}$ & $\begin{array}{l}47, X Y, G+ \\
46, X X \\
46, X Y \\
\end{array}$ & & & $\begin{array}{l}15 \\
15 \\
\end{array}$ & 10 & & $\begin{array}{l}10 \\
15 \\
15\end{array}$ & \\
\hline 71. $\quad 17.6 .66$ & 517 & $\mathbf{P}$ & $47, \mathrm{XY}, \mathrm{G}+$ & & & & 10 & & 10 & \\
\hline $\begin{array}{rr} & 24.9 .64 \\
72 . & 25.6 .65 \\
& 2.7 .65 \\
\end{array}$ & $\begin{array}{r}30 \\
229 \\
231 \\
\end{array}$ & $\begin{array}{l}\mathbf{P} \\
\mathbf{M} \\
\mathbf{F}\end{array}$ & $\begin{array}{l}\text { 47,XY, }, \mathrm{G}+ \\
46, \mathrm{XX} \\
46, \mathbf{X Y}\end{array}$ & & & $\begin{array}{l}21 \\
20 \\
\end{array}$ & $\begin{array}{r}20 \\
1\end{array}$ & & $\begin{array}{l}20 \\
22 \\
20\end{array}$ & $2 \mathrm{Cu} ; 1(47)$ \\
\hline $\begin{array}{ll} & 27.7 .66 \\
73 . & 27.7 .66 \\
& 27.7 .66 \\
\end{array}$ & $\begin{array}{l}527 \mathrm{C} \\
527 \mathrm{M} \\
527 \mathrm{~F}\end{array}$ & $\begin{array}{l}\mathbf{P} \\
\mathbf{M} \\
\mathrm{F}\end{array}$ & $\begin{array}{l}47, \mathrm{XY}, \mathrm{G}+ \\
46, \mathrm{XX} \\
46, \mathrm{XY}\end{array}$ & & & $\begin{array}{r}1 \\
10 \\
10 \\
\end{array}$ & 10 & 1 & $\begin{array}{l}11 \\
10 \\
11\end{array}$ & $1(48)$ \\
\hline $\begin{array}{ll} & 24.11 .64 \\
24.11 .64 \\
\end{array}$ & $\begin{array}{l}87 \\
86 \\
\end{array}$ & $\begin{array}{l}\mathbf{M} \\
\mathbf{F}\end{array}$ & $\begin{array}{l}46, X X \\
46, X Y \\
\end{array}$ & & & $\begin{array}{l}20 \\
12 \\
\end{array}$ & & & $\begin{array}{l}20 \\
12 \\
\end{array}$ & 3brks; $1 \mathrm{Cu}_{\mathrm{u}}$ \\
\hline $\begin{array}{ll} & 27.5 .66 \\
27.5 .66 \\
\quad 31.5 .66\end{array}$ & $\begin{array}{l}511 \mathrm{C} \\
511 \mathrm{M} \\
511 \mathrm{~F}\end{array}$ & $\begin{array}{l}\mathbf{P} \\
\mathbf{M} \\
\mathbf{F}\end{array}$ & $\begin{array}{l}\text { 47,XX, } \mathrm{X}+ \\
\text { 46,XX } \\
46, \mathrm{XY}\end{array}$ & & 1 & $\begin{array}{l}15 \\
15 \\
\end{array}$ & 10 & & $\begin{array}{l}10 \\
15 \\
15\end{array}$ & \\
\hline $\begin{array}{ll}\text { 76. } & 21.8 .64 \\
& 23.8 .65\end{array}$ & $\begin{array}{r}14 \\
258\end{array}$ & $\begin{array}{l}\mathbf{M} \\
\mathbf{F}\end{array}$ & $\begin{array}{l}46, X X \\
46, X Y\end{array}$ & & 2 & $\begin{array}{l}25 \\
20\end{array}$ & & & $\begin{array}{l}25 \\
20\end{array}$ & $1 \mathrm{Cs}_{\mathrm{s}}$ \\
\hline $\begin{array}{r}9.2 .65 \\
77 . \quad 9.2 .65 \\
1.12 .64 \\
\end{array}$ & $\begin{array}{r}150 \\
149 \\
96 \\
\end{array}$ & $\begin{array}{l}\mathbf{P} \\
\mathbf{M} \\
\mathrm{F}\end{array}$ & $\begin{array}{l}\text { 47,XX,G + } \\
46, X X \\
46, X Y \\
\end{array}$ & & & $\begin{array}{l}20 \\
15 \\
\end{array}$ & 20 & & $\begin{array}{l}20 \\
20 \\
15\end{array}$ & \\
\hline $\begin{array}{ll}78 . & 10.9 .64 \\
& 10.6 .65\end{array}$ & $\begin{array}{r}23 \\
216\end{array}$ & $\begin{array}{l}\mathbf{P} \\
\mathbf{M}\end{array}$ & $\begin{array}{l}47, \mathrm{XX}, \mathrm{G}+ \\
46, \mathrm{XX}\end{array}$ & & & 25 & 20 & & $\begin{array}{l}20 \\
25 \\
\end{array}$ & \\
\hline $\begin{array}{ll} & 17.12 .65 \\
\star 79 . \quad 17.12 .65 \\
17.12 .65\end{array}$ & $\begin{array}{l}312 \\
311 \\
310\end{array}$ & $\begin{array}{l}\mathbf{P} \\
\mathbf{F}\end{array}$ & $\begin{array}{l}47, X Y, G+ \\
46, X X \\
46, X Y\end{array}$ & & 1 & $\begin{array}{l}19 \\
24 \\
\end{array}$ & $\begin{array}{r}20 \\
1 \\
\end{array}$ & & $\begin{array}{l}20 \\
20 \\
25\end{array}$ & $1(47)$ \\
\hline $\begin{array}{ll} & 3.11 .64 \\
80 . \quad 3.11 .64 \\
& 3.11 .64 \\
\end{array}$ & $\begin{array}{l}67 \\
66 \\
65\end{array}$ & $\begin{array}{l}\mathrm{P} \\
\mathrm{M} \\
\mathrm{F}\end{array}$ & $\begin{array}{l}47, X X, G+ \\
46, X X \\
46, X Y\end{array}$ & & & $\begin{array}{r}1 \\
20 \\
30 \\
\end{array}$ & 23 & & $\begin{array}{l}23 \\
20 \\
30\end{array}$ & \\
\hline $\begin{array}{rr}24.11 .64 \\
81 . & 24.11 .64 \\
\end{array}$ & $\begin{array}{l}85 \\
84 \\
\end{array}$ & $\stackrel{P}{M}$ & $\begin{array}{l}47, \mathrm{XY}, \mathrm{G}+ \\
46, \mathrm{XX}\end{array}$ & & & $\begin{array}{l}? 3 \\
20 \\
\end{array}$ & 35 & $? 1$ & $\begin{array}{l}35 \\
20 \\
\end{array}$ & $2 \mathrm{Cu}_{\mathrm{u}}$ \\
\hline $\begin{array}{ll} & 8.12 .64 \\
82 . & 21.1 .65 \\
& 21.1 .65 \\
\end{array}$ & $\begin{array}{l}102 \\
131 \\
130\end{array}$ & $\begin{array}{l}\mathbf{P} \\
\mathbf{M} \\
\mathbf{F}\end{array}$ & $\begin{array}{l}\text { 47,XX, } \mathrm{X}+ \\
\text { 46,XX } \\
\text { 46,XY }\end{array}$ & 3 & & $\begin{array}{l}20 \\
15\end{array}$ & 35 & 1 & $\begin{array}{l}30 \\
20 \\
15\end{array}$ & \\
\hline $\begin{array}{lr}21.1 .65 \\
83 . \quad 21.1 .65 \\
& 12.2 .65 \\
\end{array}$ & $\begin{array}{l}133 \\
132 \\
151 \\
\end{array}$ & $\begin{array}{l}\mathbf{P} \\
\mathbf{M} \\
\mathbf{F} \\
\end{array}$ & $\begin{array}{l}47, \mathrm{XY}, \mathrm{G}+ \\
46, \mathrm{XX} \\
46, \mathrm{XY} \\
\end{array}$ & & $? 1$ & $\begin{array}{l}20 \\
20 \\
\end{array}$ & $\begin{array}{l}20 \\
? 1\end{array}$ & & $\begin{array}{l}20 \\
20 \\
20 \\
\end{array}$ & \\
\hline $\begin{array}{lr} & 3.6 .65 \\
84 . \quad 3.6 .65 \\
& 3.6 .65 \\
\end{array}$ & $\begin{array}{l}214 \\
213 \\
212 \\
\end{array}$ & $\begin{array}{l}\mathrm{P} \\
\mathrm{M} \\
\mathrm{F} \\
\end{array}$ & $\begin{array}{l}\text { 47,XY,G + } \\
46, X X \\
46, X Y \\
\end{array}$ & & 2 & $\begin{array}{l}18 \\
20 \\
\end{array}$ & 20 & & $\begin{array}{l}20 \\
20 \\
20 \\
\end{array}$ & 3brks \\
\hline $\begin{array}{lr}85 . & 1.10 .64 \\
\end{array}$ & $\begin{array}{r}38 \\
187 \\
\end{array}$ & $\stackrel{M}{\mathrm{~F}}$ & $\begin{array}{l}46, \mathrm{XX} \\
46, \mathrm{XY}\end{array}$ & & 1 & $\begin{array}{l}20 \\
20 \\
\end{array}$ & & & $\begin{array}{l}20 \\
20\end{array}$ & $1 \mathrm{C}_{\mathrm{u}}$ \\
\hline $\begin{array}{ll} & 24.5 .66 \\
86 . & 24.5 .66 \\
& 24.5 .66 \\
\end{array}$ & $\begin{array}{l}510 \mathrm{C} \\
510 \mathrm{M} \\
510 \mathrm{~F} \\
\end{array}$ & $\begin{array}{l}\mathbf{P} \\
\mathbf{M} \\
\mathbf{F}\end{array}$ & $\begin{array}{l}\text { 47,XX,G + } \\
46, \mathrm{XX} \\
46, \mathrm{XY}\end{array}$ & & & $\begin{array}{l}10 \\
10 \\
\end{array}$ & 10 & & $\begin{array}{l}10 \\
10 \\
10 \\
\end{array}$ & \\
\hline 87. $\quad 5.10 .66$ & $544 \mathrm{C}$ & $\mathbf{P}$ & $47, \mathrm{XY}, \mathrm{G}+$ & & & & 10 & & 10 & \\
\hline 88. $\begin{array}{r}20.11 .64 \\
4.5 .65 \\
20.11 .64 \\
\end{array}$ & \begin{tabular}{r|}
82 \\
196 \\
83 \\
\end{tabular} & $\begin{array}{l}\mathrm{P} \\
\mathrm{M} \\
\mathrm{F}\end{array}$ & $\begin{array}{l}47, X Y, G+ \\
46, X X \\
46, X Y \\
\end{array}$ & & & $\begin{array}{l}20 \\
20 \\
\end{array}$ & 20 & & $\begin{array}{l}20 \\
20 \\
20\end{array}$ & 2 brks \\
\hline $\begin{array}{ll}89 . & 30.8 .66 \\
& 30.8 .66 \\
\end{array}$ & $\begin{array}{l}538 \mathrm{C} \\
538 \mathrm{M}\end{array}$ & $\begin{array}{l}\mathbf{P} \\
M\end{array}$ & $\begin{array}{l}47, X Y, G+ \\
46, X X\end{array}$ & & & 10 & 10 & & $\begin{array}{l}10 \\
10\end{array}$ & lbrk \\
\hline
\end{tabular}


APPENDIX - continued

\begin{tabular}{|c|c|c|c|c|c|c|c|c|c|c|c|}
\hline \multirow{2}{*}{\multicolumn{2}{|c|}{$\begin{array}{l}\text { Family No. } \\
\text { and Date of } \\
\text { Culture }\end{array}$}} & \multirow[t]{2}{*}{$\begin{array}{c}\text { Culture } \\
\text { Refer- } \\
\text { ence }\end{array} \mid$} & \multirow[t]{2}{*}{ Status } & \multirow[t]{2}{*}{ 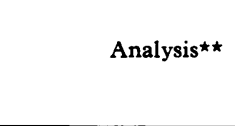 } & \multicolumn{5}{|c|}{$\begin{array}{c}\text { Distribution } \\
\text { of } \\
\text { Chromosome Counts }\end{array}$} & \multirow{2}{*}{$\begin{array}{l}\text { Total No. } \\
\text { of Cells } \\
\text { Analysed }\end{array}$} & \multirow{2}{*}{$\begin{array}{c}\text { No. of Cells } \\
\text { With } \\
\text { Variable } \\
\text { Anomalies }\end{array}$} \\
\hline & & & & & $<45$ & 45 & 46 & 47 & $>47$ & & \\
\hline 90. & $\begin{array}{l}11.11 .64 \\
18.12 .64 \\
\end{array}$ & $\begin{array}{r}76 \\
113 \\
\end{array}$ & $\begin{array}{l}\mathbf{P} \\
\mathbf{F}\end{array}$ & $\begin{array}{l}47, \mathrm{XX}, \mathrm{G}+ \\
46, \mathrm{XY}\end{array}$ & & & 20 & 20 & & $\begin{array}{l}20 \\
20\end{array}$ & \\
\hline 91. & $\begin{array}{r}24.8 .65 \\
24.8 .65 \\
3.9 .65\end{array}$ & $\begin{array}{l}259 \\
260 \\
262\end{array}$ & $\begin{array}{l}\mathbf{P} \\
\mathbf{M} \\
\mathrm{F}\end{array}$ & $\begin{array}{l}\text { 47,XX, }, \mathrm{G}+ \\
46, \mathrm{XX} \\
46, \mathrm{XY}\end{array}$ & & & $\begin{array}{l}20 \\
20\end{array}$ & 20 & & $\begin{array}{l}20 \\
20 \\
20\end{array}$ & \\
\hline 92. & $\begin{array}{l}5.11 .64 \\
5.11 .64\end{array}$ & $\begin{array}{l}71 \\
72\end{array}$ & $\begin{array}{l}\mathbf{M} \\
\mathbf{F}\end{array}$ & $\begin{array}{l}46, X X \\
46, X Y\end{array}$ & & 2 & $\begin{array}{l}18 \\
20\end{array}$ & & & $\begin{array}{l}30 \\
20\end{array}$ & \\
\hline 93. & $\begin{array}{r}11.6 .65 \\
5.4 .65 \\
5.4 .65\end{array}$ & $\begin{array}{l}217 \\
180 \\
179 \\
\end{array}$ & $\begin{array}{l}\mathbf{P} \\
\mathbf{M} \\
\mathbf{F}\end{array}$ & $\begin{array}{l}47, \mathbf{X Y}, G+ \\
46, \mathbf{X X} \\
46, X Y\end{array}$ & & & $\begin{array}{l}20 \\
20 \\
\end{array}$ & 20 & & $\begin{array}{l}20 \\
20 \\
20 \\
\end{array}$ & $2 \mathrm{Cu}_{\mathrm{u}}$ \\
\hline 94. & $\begin{array}{r}15.1 .65 \\
16.10 .64 \\
11.10 .65\end{array}$ & $\begin{array}{r}122 \\
54 \\
279\end{array}$ & $\begin{array}{l}\mathbf{P} \\
\mathbf{M} \\
\mathbf{F}\end{array}$ & $\begin{array}{l}47, X Y, G+ \\
46, X X \\
46, X Y\end{array}$ & & & $\begin{array}{r}1 \\
20 \\
20\end{array}$ & 19 & & $\begin{array}{l}20 \\
20 \\
20\end{array}$ & $2 \mathrm{brks} ; 2 \mathrm{C}_{\mathrm{u}}$ \\
\hline 95. & $\begin{array}{l}10.8 .65 \\
10.8 .65 \\
10.8 .65\end{array}$ & $\begin{array}{l}248 \\
247 \\
246 \\
\end{array}$ & $\begin{array}{l}\mathbf{P} \\
\mathbf{M} \\
\mathbf{F}\end{array}$ & $\begin{array}{l}\text { 47,XX,G+ } \\
46, X X, G p+ \\
46, X Y\end{array}$ & & & $\begin{array}{l}20 \\
20\end{array}$ & 20 & & $\begin{array}{l}20 \\
20 \\
20\end{array}$ & 1brk \\
\hline 96. & 4.8 .64 & 7 & $\mathbf{P}$ & $47, \mathrm{XX}, \mathrm{G}+$ & & & & 20 & & 20 & \\
\hline
\end{tabular}

P, patient; $M$, mother; F, Father, brk, break; dim, dimorphism.

$\star$ Chromosomes of one or more sibs also examined (not shown in the Appendix).

+ Mother had 6 miscarriages; mongol child was born when mother 24, father 29.

Uncle had similar Y chromosome.

Cell not included in analysis.

$\star \star$ According to Chicago Conference Standardisation in Human Genetics. 